\title{
Improvement of nitrogen management in rice paddy fields using chlorophyll meter (SPAD)
}

\author{
M. Esfahani · H. R. Ali Abbasi · B. Rabiei · \\ M. Kavousi
}

Received: 6 August 2006/Accepted: 30 October 2007/Published online: 15 November 2007

(C) The Author(s) 2007

\begin{abstract}
Optimum rate and timing application of nitrogen $(\mathrm{N})$ fertilizer are most crucial in achieving high yield in irrigated lowland rice. In order to assess leaf $\mathrm{N}$ status, a semidwarf rice cultivar (Khazar) was grown with different $\mathrm{N}$ application treatments $\left(0,40,80\right.$, and $120 \mathrm{~kg} \mathrm{~N} \mathrm{ha}^{-1}$ splited at transplanting, midtillering, and panicle initiation stages) in a sandy soil in Guilan Province, Iran, in 2003. The chlorophyll meter (SPAD 502) readings were recorded and leaf $\mathrm{N}$ concentrations were measured on the uppermost fully expanded leaf in rice plants at 10-day internals from 19 days after transplanting to grain maturity. Regression analysis showed that the SPAD readings predicted only $23 \%$ of changes in the leaf $\mathrm{N}$ concentration based on pooled data of leaf dry weight $\left(N_{\mathrm{dw}}\right)$ for all growth stages. However, adjusting the SPAD readings for specific leaf weight (SPAD/SLW) improved the estimation of $N_{\mathrm{dw}}$, up to $88 \%$. Specific leaf weight (SLW), SPAD readings, leaf area and weight as independent variables in a multiple regression analysis predicted $96 \%$ of the $N_{\mathrm{dw}}$ changes, while SPAD readings independently predicted about $80 \%$ of leaf $\mathrm{N}$ concentration changes on the basis of leaf area $\left(N_{\mathrm{a}}\right)$. It seems that chlorophyll meter provides a simple, rapid, and nondestructive method to estimate the leaf $\mathrm{N}$ concentration based on leaf area, and could be reliably exploited to predict the exact $\mathrm{N}$ fertilizer topdressing in rice.
\end{abstract}

M. Esfahani · H. R. A. Abbasi · B. Rabiei ( $\square)$

Department of Agronomy and Plant Breeding,

Faculty of Agricultural Sciences, University of Guilan,

P.O. Box 41635-1314, Rasht, Iran

e-mail: rabiei@guilan.ac.ir; babakrabiei1348@yahoo.com

M. Kavousi

Rice Research Institute of Iran (RRII),

P.O. Box 3657, Rasht, Iran
Keywords Chlorophyll meter (SPAD) .

$\mathrm{N}$ fertilizer topdressing - Nitrogen management .

Rice

\section{Introduction}

Leaf nitrogen is closely related to photosynthesis rate and grain yield in rice (Peng et al. 1995a). It is a sensitive indicator for the dynamic changes in plant nitrogen, so nitrogen status monitoring during the growing period is essential to achieve efficient nitrogen fertilizer management and higher grain yield in paddy rice. Since, most rice farmers due to its time consuming procedures (1014 days) do not generally use the direct measurement of leaf nitrogen concentration, so a method simple, rapid, and reliable field scale method is necessary to detect the leaf nitrogen status and predict the precise time and rate of nitrogen fertilizer topdressing. The chlorophyll meter provides a simple, rapid, and nondestructive method for estimating leaf chlorophyll content (Watanabe et al. 1980). Several investigators demonstrated that the leaf chlorophyll content on the basis of leaf area could be estimated using chlorophyll meter (Chubachi et al. 1986; Jiang and Vergara 1986; Yadava 1986). Since, much of leaf nitrogen is involved in enzymes associated with chlorophyll, the chlorophyll content evaluation using SPAD and its relation with leaf nitrogen concentration could provide an indirect assessment of leaf nitrogen status (Chapman and Barreto 1997).

Turner and Jund (1991) indicated that the chlorophyll meter could be used to predict the requirement of nitrogen topdressing prior to panicle initiation and panicle differentiation stages in semidwarf rice cultivars. Peng et al. (1993) reported that the estimation of leaf nitrogen 
concentration by means of chlorophyll meter was closely related to specific leaf weight (SLW). They showed that SPAD readings could justify about $49.5 \%$ of variation in the leaf nitrogen concentration based on pooled data of leaf dry weight $\left(N_{\mathrm{dw}}\right)$, but adjusting SPAD readings for SLW $\left(\mathrm{SPAD}_{\mathrm{adj}}\right)$ improved the prediction of $N_{\mathrm{dw}}\left(r^{2}=0.93\right)$ across growth stages in rice. Furthermore, Peng et al. (1995b) demonstrated that the correlation coefficient between SPAD readings and leaf nitrogen concentration based on leaf area $\left(N_{\mathrm{a}}\right)$ was more than SPAD readings and $N_{\mathrm{dw}}(r=0.81$ and $r=0.43$, respectively).

Previous studies have shown that the regression equations for leaf chlorophyll content $\left(N_{\mathrm{dw}}\right.$ or $\left.N_{\mathrm{a}}\right)$ on the chlorophyll meter reading differed markedly depending on growth stage, genotype and environmental conditions (e.g. location, radiation, soil fertility, biotic and abiotic stresses) that have been reported to confound meter calibration for $\mathrm{N}$ content estimation in rice and many plant species (Takebe and Yoneyama 1989; Peng et al. 1993; Campbell et al. 1990; Smeal and Zhang 1994; Balasubramanian et al. 2000). Peng et al. (1995b) presented that the accurate prediction of plant nitrogen status with SPAD apparatus requires an individual calibration of the relationship between SPAD readings and nitrogen concentration for different rice cultivars grown under specific growth conditions and at a specified growth stage.

The objectives of the present study were the calibration of chlorophyll meter (SPAD) in an improved rice cultivar (Khazar) grown at the northern climatic conditions of Iran and determination of the best relationship between SPAD readings and leaf nitrogen concentration based on pooled data of leaf dry weight $\left(N_{\mathrm{dw}}\right)$ and leaf area $\left(N_{\mathrm{a}}\right)$ in rice plant for prediction of leaf nitrogen using SPAD.

\section{Materials and methods}

Field experiment was conducted in a coastal light texture soil (88\% sand, $8 \%$ silt, and $4 \%$ clay) with $\mathrm{pH} 6.5$, $0.66 \mathrm{~g} \mathrm{~kg}^{-1}$ organic $\mathrm{C}, 0.07 \mathrm{~g} \mathrm{~kg}^{-1}$ total $\mathrm{N}, 89 \mathrm{mg} \mathrm{kg}^{-1}$ $\mathrm{K}, 33 \mathrm{mg} \mathrm{kg}^{-1} \mathrm{P}$, and $65 \mathrm{dsm}^{-1}$ electrical conductivity in Bandar Anzali ( $37^{\circ} 28^{\prime} \mathrm{N}, 49^{\circ} 28^{\prime} \mathrm{E}, 20 \mathrm{~m}$ down sea level), Guilan province, Iran, in 2003. The semidwarf cultivar Khazar (resulted from a crossing between TNAU7456 cultivar and a sister line of IR36 named IR2081-62-1-52), with $110 \mathrm{~cm}$ plant height and around 130 days growth duration was grown in a wet bed nursery. Twenty-fivedays-old seedlings were transplanted on May 20 with spacing of $20 \times 20 \mathrm{~cm}$ and four plants per hill. Six Nitrogen fertilizer rates (in urea form) were applied in a randomized complete block design with three replications and splited at transplanting (basal, BA), midtillering (34 days after transplanting, MT) and panicle initiation
(53 days after transplanting, PI) and compared with nitrogen free plots as control treatment (Table 1). All plots were $30 \mathrm{~m}^{2}$ and received $45 \mathrm{~kg} / \mathrm{ha} \mathrm{P}$ (in superphosphat triple form) and $100 \mathrm{~kg} / \mathrm{ha} \mathrm{K}$ (in $\mathrm{K}_{2} \mathrm{SO}_{4}$ form) and incorporated in the soil 1 day before transplanting. Field was flooded 1 day after transplanting (DAY) and the water depth was maintained at $5-10 \mathrm{~cm}$ until 7 days before maturity. Weeds, insects, and diseases were controlled according to conventional management procedure.

A chlorophyll meter [SPAD-502, Soil and plant analysis development (SPAD), Minolta Camera Co. Osaka, Japan] was used for chlorophyll measurement on ten top fully expanded leaves (i.e. index leaves) per plot at 19, 29, 39, 49, 59, 69, 79, 89 and 99 DAY, and three SPAD readings (dimensionless values, 650/940 $\mathrm{nm}$ wave lengths transmittance ratio) were taken around the midpoint of each leaf blade, $30 \mathrm{~mm}$ apart from one side of the midrib. Thirty SPAD readings were averaged to represent the mean SPAD readings of each plot. After SPAD readings, ten leaves from each plot were pooled for measuring leaf area (LA) $\left(\mathrm{m}^{-2}\right)$, leaf weight $(\mathrm{LW})(\mathrm{g})$, specific leaf weight (SLW) $\left(\mathrm{g} \mathrm{m}^{-2}\right)$, and $\mathrm{N}$ concentration. Leaf area was measured on site by weighting method (in order to avoid leaves shrinkage, furthermore by a leaf area meter, LI 3100, LiCor, Lincoln, NE) and dry weight was recorded after oven drying at $70^{\circ} \mathrm{C}$ for $72 \mathrm{~h}$. SLW was calculated as the ratio of dry weight to leaf area. Leaf $\mathrm{N}$ concentration was determined by Kjeldahl digestion and distillation (Chapman and Pratt 1961), and expressed on the basis of leaf dry weight $\left(N_{\mathrm{dw}}\right)$ and area $\left(N_{\mathrm{a}}\right)$.

Simple and multiple regression analysis were performed (SPSS 1999) between $N_{\mathrm{dw}}, N_{\mathrm{a}}$, SPAD readings, and SPA$\mathrm{D}_{\text {adj }}$ values using data from each growth stage and pooled data across growth stages. Correlation coefficients between all variables were also determined at all stages using SAS program (SAS Institute 1996).

Table 1 Nitrogen fertilizer application treatments at three crop growth stages

\begin{tabular}{lccc}
\hline \multirow{2}{*}{ Treatment } & \multicolumn{2}{l}{ Nitrogen fertilizer rates $(\mathrm{kg} / \mathrm{ha})^{\mathrm{a}}$} \\
\cline { 2 - 4 } & $\mathrm{BA}$ & MT & PI \\
\hline Control & - & - & - \\
(T2) & 40 & - & - \\
(T3) & 40 & 40 & - \\
(T4) & 40 & 20 & 20 \\
(T5) & 60 & 60 & - \\
(T6) & 60 & 30 & 30 \\
\hline
\end{tabular}

$\overline{{ }^{a}}$ BA, MT and PI represents basal, mid-tillering and panicle initiation growth stages 
Table 2 Correlation coefficients $(r)$ between chlorophyll meter (SPAD) readings and nitrogen concentration based on leaf dry weight $\left(N_{\mathrm{dw}}\right)$ and leaf area $\left(N_{\mathrm{a}}\right)$, and between $N_{\mathrm{dw}}$ and adjusted SPAD readings $\left(\mathrm{SPAD}_{\mathrm{adj}}\right)$ by specific leaf weight $(\mathrm{SPAD} / \mathrm{SLW})$ at days after transplanting (DAY)

\begin{tabular}{|c|c|c|c|c|}
\hline \multirow[t]{2}{*}{ DAY } & \multirow{2}{*}{$\begin{array}{l}\text { Number of } \\
\text { observations }\end{array}$} & \multicolumn{3}{|c|}{ Correlation coefficients } \\
\hline & & $\begin{array}{l}\text { SPAD } \\
\text { and } N_{\mathrm{dw}}\end{array}$ & $\begin{array}{l}\text { SPAD } \\
\text { and } N_{\mathrm{a}}\end{array}$ & $\begin{array}{l}\text { SPAD }_{\text {adj }} \\
\text { and } N_{\text {dw }}\end{array}$ \\
\hline 19 & 18 & $0.909 * *$ & $0.935 * *$ & $0.917 * *$ \\
\hline 29 & 18 & $0.862 * *$ & $0.984 * *$ & $0.969 * *$ \\
\hline 39 & 18 & $0.859 * *$ & $0.981 * *$ & $0.903 * *$ \\
\hline 49 & 18 & $0.860 * *$ & $0.934 * *$ & $0.936^{* *}$ \\
\hline 59 & 18 & $0.739 * *$ & $0.969 * *$ & $0.992 * *$ \\
\hline 69 & 18 & $0.939 * *$ & $0.969 * *$ & $0.854 * *$ \\
\hline 79 & 18 & $0.906 * *$ & $0.984 * *$ & $0.833 * *$ \\
\hline 89 & 18 & $0.925 * *$ & $0.987 * *$ & $0.872 * *$ \\
\hline 99 & 18 & $0.881 * *$ & $0.957 *$ & $0.943 * *$ \\
\hline Pooled & 162 & $0.486 * *$ & $0.897 * *$ & $0.914 * *$ \\
\hline
\end{tabular}

SPAD Soil and plant analysis development (Minolta Co. Ltd.)

** Significant at $1 \%$ level of probability

\section{Results}

Results showed a positive significant correlation ( $P$ $\leq 0.01$ ) between $N_{\mathrm{dw}}$ and SPAD readings at each growth stage and pooled data for all stages (Table 2). Regression analysis indicated that there was a significant linear regression between $N_{\mathrm{dw}}$ and SPAD readings within and across growth stages. For the pooled data of the nine sampling dates, relationship between $N_{\mathrm{dw}}$ and SPAD readings was poor $\left(r^{2}=0.232\right)$, and only about $23 \%$ of variation in $N_{\mathrm{dw}}$ was explained by chlorophyll meter reading (Table 3; Fig. 1).

$N_{\mathrm{dw}}=2.1397 \mathrm{SPAD}-47.759 \quad\left(R^{2}=0.232\right)$

Stepwise regression analysis indicated that SLW, SPAD readings, LA and LW as independent variables, significantly $(P \leq 0.01)$ explained the variability of $N_{\mathrm{dw}}$ (Table 4$)$ :

$$
\begin{aligned}
N_{\mathrm{dw}}= & 2.108 \mathrm{SPAD}-0.836 \mathrm{SLW}-11842.5 \mathrm{LA} \\
& +175.18 \mathrm{LW} \quad\left(R^{2}=0.959\right)
\end{aligned}
$$

According to Eq. 2, the total predictable variation of $N_{\mathrm{dw}}$ on the basis of SPAD readings (18.5\%), SLW (68.3\%), LA $(2.9 \%)$, and LW (6.3\%), was about $96 \%$, which was about $72.7 \%$ more than Eq. 1. Furthermore, regression analysis at each sampling stage showed that SLW as the first or second independent variable increased the determination coefficient of regression model, and the multiple regression predicted $N_{\mathrm{dw}}$ changes precisely rather than the simple regression (Table 7). These results showed that SLW affected the chlorophyll meter readings, and increased the accuracy of $N_{\mathrm{dw}}$ prediction by the chlorophyll meter. The leaf $\mathrm{N}$ concentration based on pooled data of leaf dry weight $\left(N_{\mathrm{dw}}\right)$ on top fully expanded leaves generally decreased and

Table 3 Regression analysis (pooled) between chlorophyll meter (SPAD) readings and nitrogen concentration based on leaf dry weight ( $\left.N_{\mathrm{dw}}\right)$

\begin{tabular}{|c|c|c|c|c|c|c|c|c|}
\hline & \multirow[t]{2}{*}{ Source of variation } & \multirow[t]{2}{*}{$d f$} & \multirow[t]{2}{*}{ MS } & \multirow[t]{2}{*}{$R_{\mathrm{adj}}^{2}$} & \multirow[t]{2}{*}{ Intercept } & \multicolumn{3}{|c|}{ Slope of regression } \\
\hline & & & & & & Linear & Quadratic & Cubic \\
\hline \multirow[t]{4}{*}{ SPAD and $N_{\mathrm{dw}}$} & Linear & 1 & $4734.052^{* *}$ & 0.232 & $-47.7586^{* *}$ & $2.1397 * *$ & & \\
\hline & Residual & 160 & 95.513 & & & & & \\
\hline & Quadratic & 2 & $2367.041 * *$ & 0.226 & $-50.2054^{\mathrm{ns}}$ & $2.2776^{\mathrm{ns}}$ & $0.0019^{\mathrm{ns}}$ & \\
\hline & Residual & 159 & 96.114 & & & & & \\
\hline \multirow[t]{4}{*}{ SPAD and $N_{\mathrm{a}}$} & Linear & 1 & $15.579 * *$ & 0.803 & $-2.9336 * *$ & $0.1227 * *$ & & \\
\hline & Residual & 160 & 0.0236 & & & & & \\
\hline & Quadratic & 2 & $7.859 * *$ & 0.809 & $-2.3526^{\mathrm{ns}}$ & $0.1751^{\mathrm{ns}}$ & $0.0042^{\text {ns }}$ & \\
\hline & Residual & 159 & 0.0229 & & & & & \\
\hline \multirow[t]{6}{*}{$\mathrm{SPAD}_{\mathrm{adj}}$ and $N_{\mathrm{dw}}$} & Linear & 1 & $16722.90 * *$ & 0.834 & $-5.8936^{*}$ & $48.6569^{* *}$ & & \\
\hline & Residual & 160 & 20.583 & & & & & \\
\hline & Quadratic & 2 & $8627.92 * *$ & 0.860 & $-27.2456^{* *}$ & $107.5377 * *$ & $-37.1233^{* *}$ & \\
\hline & Residual & 159 & 17.360 & & & & & \\
\hline & Cubic & 3 & $5880.72 * *$ & 0.879 & $41.9087 * *$ & $-185.1965^{* *}$ & $352.8336 * *$ & $-136.2711 * *$ \\
\hline & Residuals & 158 & 15.025 & & & & & \\
\hline
\end{tabular}
and leaf area $\left(N_{\mathrm{a}}\right)$, and between $N_{\mathrm{dw}}$ and adjusted SPAD readings (SPAD adj) by specific leaf weight (SPAD/SLW) at all growth stages

SPAD Soil and plant analysis development (Minolta Co. Ltd.)

ns Non significant

* Significant at $5 \%$ level of probability

** Significant at $1 \%$ level of probability 


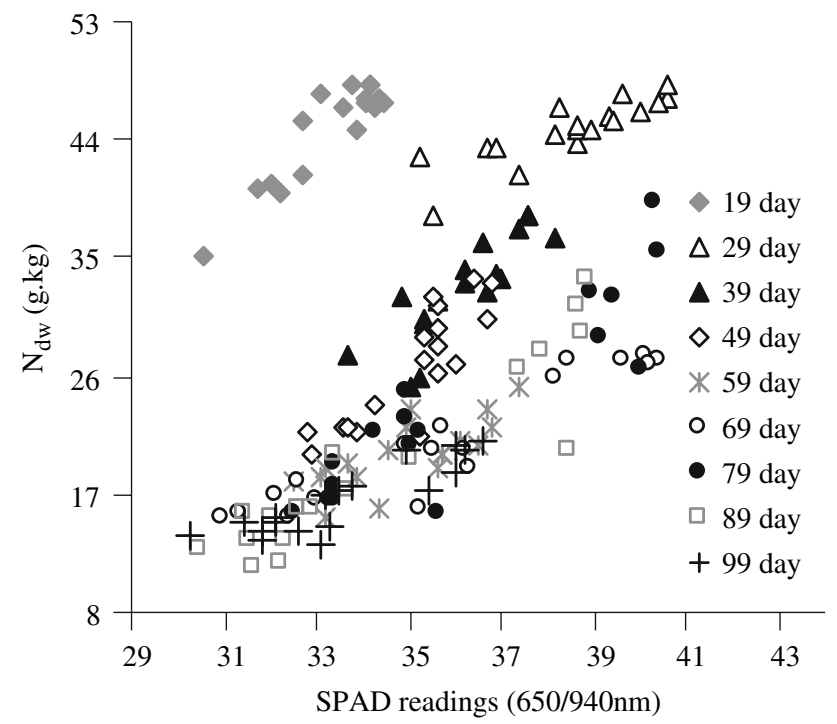

Fig. 1 Relationship between nitrogen concentrations based on leaf dry weight $\left(N_{\mathrm{dw}}\right)$ and chlorophyll meter (SPAD) readings for pooled data at all growth stages

SLW increased with plant age (Table 5), and there was an integrated divergent trends in $N_{\mathrm{dw}}$ and SLW. A negative and significant correlation between SLW and $N_{\mathrm{dw}}(r=-0.827)$ has been observed for pooled data and SLW had a reciprocal relationship with SPAD readings for explaining the changes of $N_{\mathrm{dw}}$ at the multiple regression (Table 4, Eq. 2). It's been seen that thicker leaves promoted SPAD readings without increase in leaf $\mathrm{N}$ concentration. Therefore in order to eliminate the effect of SLW on SPAD values, SPAD readings were adjusted based on SLW (SPAD/SLW) and were defined as $\mathrm{SPAD}_{\mathrm{adj}}=\mathrm{SPAD} / \mathrm{SLW}$. Regression analysis showed that the $\mathrm{SPAD}_{\text {adj }}$ values (for pooled data) had a cubic relationship with $N_{\mathrm{dw}}$ (Table 3; Fig. 2):

$$
\begin{aligned}
N_{\mathrm{dw}}= & -163.271 \mathrm{SPAD}_{\mathrm{adj}}^{3}+352.834 \mathrm{SPAD}_{\mathrm{adj}}^{2} \\
& -185.196 \mathrm{SPAD}_{\mathrm{adj}}+41.909 \quad\left(R^{2}=0.878\right)
\end{aligned}
$$

In comparison with SPAD readings, $\mathrm{SPAD}_{\text {adj }}$ values increased probable prediction of total variation in $N_{\mathrm{dw}}$ from 23 to $88 \%$ for pooled data at all stages (Table 3; Fig. 1 vs. Fig. 2).

Evaluation of the correlation coefficients showed that there was no significant correlation between $N_{\mathrm{dw}}$ and SPAD readings, but $\mathrm{SPAD}_{\text {adj }}$ values had significant correlation with $N_{\mathrm{dw}}$ (Table 6). Although, during the growth period, SPAD ${ }_{\text {adj }}$ values indicated closer linear correlation with $N_{\mathrm{dw}}$ than SPAD readings at 19, 29, 39, 49, 59, and 99 DAY and pooled data in all stages, but it decreased at 69, 79, and 89 DAY (after panicle initiation and flowering stages) (Table 4).

Regression analysis showed that there was a significant linear regression between $N_{\mathrm{a}}$ and SPAD readings within each growth stage (data not shown) and for pooled data across growth stages (Table 2; Fig. 3). SPAD readings (for pooled data) explained a higher contribution of $N_{\mathrm{a}}$ changes than $N_{\mathrm{dw}}$ (80 vs. $23 \%$, respectively) (Table 3 ; Eq. 4 ). In addition, a significant correlation was observed between $N_{\mathrm{a}}$ and SPAD readings in both within treatments and growth stages (Tables 2, 6):

$N_{\mathrm{a}}=0.1227 \mathrm{SPAD}-2.9337 \quad\left(R^{2}=0.803\right)$

Based on Eq. 5, the improved estimation of change of $N_{\mathrm{a}}$ on the basis of SPAD readings (80.5\%), LA (4.3\%), LW $(1.4 \%)$, and SLW $(1.1 \%)$, was up to $87.1 \%$, which was only $6.8 \%$ more than Eq. 4. The SLW had the least effect on relationship between $N_{\mathrm{a}}$ and SPAD readings (Table 5). Since, SPAD values explained, with reasonable accuracy, $80 \%$ of total variation in $N_{\mathrm{a}}$ across growth stages, thus it

Table 4 Multiple regression analysis between leaf nitrogen concentration based on leaf dry weight $\left(N_{\mathrm{dw}}\right)$ and chlorophyll meter (SPAD)

\begin{tabular}{|c|c|c|c|c|c|c|c|c|}
\hline \multirow[t]{2}{*}{ Regression model } & \multirow[t]{2}{*}{$d f$} & \multirow[t]{2}{*}{ MS } & \multirow[t]{2}{*}{$R_{\mathrm{adj}}^{2}$} & \multicolumn{5}{|c|}{ Regression coefficients } \\
\hline & & & & Intercept & SLW $\left(\mathrm{g} \mathrm{m}^{-2}\right)$ & SPAD & $\mathrm{LA}\left(\mathrm{m}^{-2}\right)$ & LW (g) \\
\hline SLW & 1 & $13695.56^{* *}$ & 0.682 & $65.07^{* *}$ & $-0.768^{* *}$ & & & \\
\hline Residuals & 160 & 39.504 & & & & & & \\
\hline SLW, SPAD & 2 & $8690.02^{* *}$ & 0.867 & $3.074^{\mathrm{ns}}$ & $-0.655^{* *}$ & $1.892^{* *}$ & & \\
\hline Residuals & 159 & 16.6 & & & & & & \\
\hline SLW, SPAD, LA & 3 & $5992.81^{* *}$ & 0.896 & $-14.548^{* * *}$ & $-0.47 * *$ & $2.105^{* *}$ & $-2521.66^{* *}$ & \\
\hline Residuals & 158 & 12.9 & & & & & & \\
\hline SLW, SPAD, LA, LW & 4 & $4801.2^{* *}$ & 0.959 & $2.388^{\mathrm{ns}}$ & $-0.836^{* *}$ & $2.108^{* *}$ & $-11842.5^{* *}$ & $175.18^{* *}$ \\
\hline Residuals & 157 & 5.17 & & & & & & \\
\hline
\end{tabular}
readings, leaf weight (LW), leaf area (LA), and specific leaf weight (SLW) for pooled data at all growth stages

SPAD Soil and plant analysis development (Minolta Co. Ltd.)

ns Non significant

** Significant at $1 \%$ level of probability 
Table 5 Multiple regression analysis between leaf nitrogen concentration based on leaf area $\left(N_{\mathrm{a}}\right)$ and chlorophyll meter (SPAD) readings, leaf weight (LW), leaf area (LA), and specific leaf weight (SLW) for pooled data at all growth stages

\begin{tabular}{|c|c|c|c|c|c|c|c|c|}
\hline \multirow[t]{2}{*}{ Regression model } & \multirow[t]{2}{*}{$d f$} & \multirow[t]{2}{*}{ MS } & \multicolumn{6}{|c|}{ Regression coefficients } \\
\hline & & & $R_{\mathrm{adj}}^{2}$ & Intercept & SPAD & LA $\left(m^{-2}\right)$ & LW (g) & SLW $\left(\mathrm{g} \mathrm{m}^{-2}\right)$ \\
\hline SPAD & 1 & $15.579 * *$ & 0.803 & $-2.9336^{* *}$ & $0.123 * *$ & & & \\
\hline Residuals & 160 & 0.0236 & & & & & & \\
\hline SPAD-LA & 2 & $8.213 * *$ & 0.846 & $-2.907 * *$ & $0.126 * *$ & $-57.867 * *$ & & \\
\hline Residuals & 159 & 0.0185 & & & & & & \\
\hline SPAD-LA-LW & 3 & $5.57 * *$ & 0.86 & $-2.975^{* *}$ & $0.129 * *$ & $-185.447 * *$ & $1.795 * *$ & \\
\hline Residuals & 158 & 0.0168 & & & & & & \\
\hline SPAD-LA-LW-SLW & 4 & $4.233 * *$ & 0.871 & $-2.612 * *$ & $0.127 * *$ & $-251.973 * *$ & $3.533 * *$ & $-0.00666 * *$ \\
\hline Residuals & 157 & 0.0155 & & & & & & \\
\hline
\end{tabular}

SPAD Soil and plant analysis development (Minolta Co. Ltd.)

** Significant at $1 \%$ level of probability

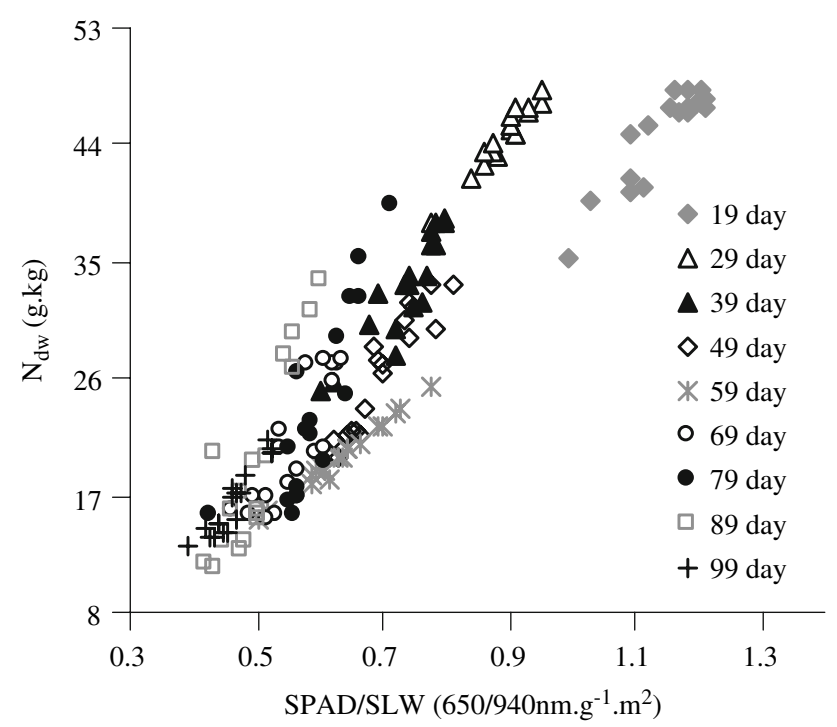

Fig. 2 Relationship between nitrogen concentrations based on leaf dry weight $\left(N_{\mathrm{dw}}\right)$ and adjusted chlorophyll meter (SPAD) readings (SPAD/SLW) for pooled data at all growth stages

seems that there is no need for adjusted SPAD readings with SLW in Eq. 4.

$$
\begin{aligned}
N_{\mathrm{a}}= & 0.127(\mathrm{SPAD})-251.973(\mathrm{LA})+3.533(\mathrm{LW}) \\
& -0.00666(\mathrm{SLW})-2.612 \quad R^{2}=0.871
\end{aligned}
$$

\section{Discussion}

Based on results of the present study, there was a poorer relationship between $N_{\mathrm{dw}}$ and SPAD readings for pooled data of the nine growth stages $\left(r^{2}=0.23\right)$ than each growth stage $\left(r^{2}=0.52-0.87\right)$. It seems that, this was due to the regression line slope variations between $N_{\mathrm{dw}}$ and SPAD readings within the nine sampling stages. Comparison of the simple regression coefficients indicated that there were significant differences $(P \leq 0.05)$ between the linear regression coefficients of $19,39,49$, and 79 versus 29,59 , 69, and 99 DAY (Table 7). Therefore, when data of the nine sampling stages were pooled, the coefficient of determination $\left(R^{2}\right)$ considerably decreased due to the significant regression slopes at different growth stages. Peng et al. (1995b) reported a poor linear correlation between $N_{\mathrm{dw}}$ and SPAD readings for pooled data of ten growth stages $(r=0.43)$ in comparison with each sampling stage $(r=0.70-0.86)$.

Peng et al. (1993) had also demonstrated that the leaf thickness variation (SLW) was the main reason for variable relationship between $N_{\mathrm{dw}}$ and SPAD readings. In comparison with the effects of growth stages (Table 7), the effect of $\mathrm{N}$ fertilizer on the SLW was minor and inconsistent in this study (data not shown). In general, the mean comparisons showed that $N_{\mathrm{dw}}$ of the uppermost fully expanded leaves significantly decreased, but SLW increased as plant growth proceeded. This finding was similar to the results of Peng et al. (1995b). Therefore, the closer correlation between $N_{\mathrm{dw}}$ and SPAD readings at each growth stage than across growth stages may be due to the lower variation in SLW within a stage than all stages (Table 4). In addition, the regression equation between $N_{\mathrm{dw}}$ and SPAD readings was improved when SPAD readings were adjusted for SLW (Eq. 1 vs. Eq. 3), and/or SLW was entered in the multiple regression as a first or second independent variable (Table 7; Eq. 1 vs. Eq. 2). This may be related to difference in leaf thickness. In fact, leaf thickness may lead to increase in number of mesophyll and palisade cells layer in leaf blade. This may result in higher and much efficient light guide within palisade cells toward mesophyll spongy cells to eliminate light dilution (reflection, refraction and 
Table 6 Correlation coefficients of nitrogen concentration based on leaf dry weight $\left(N_{\mathrm{dw}}\right)$, leaf area $\left(N_{\mathrm{a}}\right)$ and chlorophyll meter (SPAD) readings, and between $N_{\mathrm{dw}}$ and adjusted SPAD readings (SPAD ${ }_{\text {adj }}$ ) by specific leaf weight (SPAD/SLW) in various experimental treatments

\begin{tabular}{lllll}
\hline Treatment & $\begin{array}{l}\text { Number of } \\
\text { observations }\end{array}$ & \multicolumn{3}{l}{ Correlation coefficients } \\
\cline { 3 - 5 } & & $\begin{array}{l}\text { SPAD } \\
\text { and } N_{\mathrm{dw}}\end{array}$ & $\begin{array}{l}\text { SPAD } \\
\text { and } N_{\mathrm{dw}}\end{array}$ & $\begin{array}{l}\text { SPAD } \\
\text { and } N_{\mathrm{a}}\end{array}$ \\
\hline Control & 9 & $0.933^{* *}$ & $0.463^{\mathrm{ns}}$ & $0.821^{* *}$ \\
(T2) & 9 & $0.941^{* *}$ & $0.572^{\mathrm{ns}}$ & $0.935^{* *}$ \\
(T3) & 9 & $0.945^{* *}$ & $0.555^{\mathrm{ns}}$ & $0.836^{* *}$ \\
(T4) & 9 & $0.868^{* *}$ & $0.105^{\mathrm{ns}}$ & $0.854^{* *}$ \\
(T5) & 9 & $0.936^{* *}$ & $0.619^{\mathrm{ns}}$ & $0.872^{* *}$ \\
(T6) & 9 & $0.900^{* *}$ & $0.170^{\mathrm{ns}}$ & $0.902^{* *}$ \\
\hline
\end{tabular}

ns Non significant

** Significant at $1 \%$ level of probability

SPAD Soil and Plant Analysis Development (Minolta Co. Ltd.)

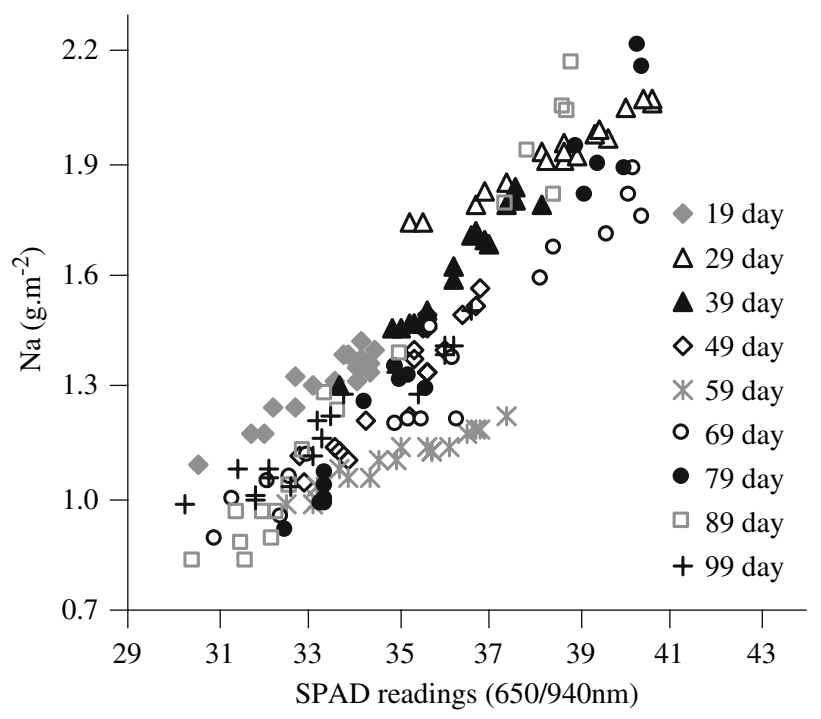

Fig. 3 Relationship between nitrogen concentrations based on leaf area $\left(N_{\mathrm{a}}\right)$ and chlorophyll meter (SPAD) readings for pooled data at all growth stages

scatter). The transmitted light could be absorbed by chloroplast of mesophyll spongy cells, and may lead to higher photosynthetic efficiency (Taiz and Zeiger 1991). The chlorophyll meter estimates the chlorophyll content of a leaf based on the intensities of transmitted red band (around $650 \mathrm{~nm}$ ), which is highly absorbed by chlorophyll, and in the infrared band (around $940 \mathrm{~nm}$ ) where absorption is low (Minolta 1989). Therefore, SLW, which is related to leaf thickness (Chiariello et al. 1989) affected SPAD readings and prediction of $N_{\mathrm{dw}}$. Peng et al. (1992) reported that thick leaves increased SPAD readings and thicker leaves (i.e. higher SLW) absorbed red light more than infrared light in leaves with similar chlorophyll content on the basis of leaf area. Peng et al. (1993) also demonstrated that SLW in the multiple regression improved prediction of $N_{\mathrm{dw}}$ than simple regression similar to $\mathrm{SPAD}_{\mathrm{adj}}$, because differences in leaf thickness contributed to the variability in the linear relationship between $N_{\mathrm{dw}}$ and SPAD readings (Campbell et al. 1990). The nonlinear relationship between $N_{\mathrm{dw}}$ and $\operatorname{SPAD}_{\text {adj }}$ (Eq. 3) observed in the present experiment may be due to the same reason.

Marquard and Tipton (1987) reported a stronger relationship between chlorophyll meter readings and chlorophyll concentration based on leaf area than leaf weight. Besides, chlorophyll content in a leaf is closely correlated with leaf N concentration (Evans 1983; Blackmer and Schepers 1994). Based on these findings, it is expected that SPAD readings predicted more contribution from the variation in $N_{\mathrm{a}}$. Peng et al. (1995b) indicated that chlorophyll meter estimates $N_{\mathrm{a}}$ better than $N_{\mathrm{dw}}$ within and across growth stages, and SLW has a minor effect on the relationship between $N_{\mathrm{a}}$ and SPAD readings. Results of the present study also support this finding, that SPAD readings explained $80 \%$ of the total variation in $N_{\mathrm{a}}$ across growth stages (Eq. 4).

Chlorophyll content prediction on leaf area basis has been demonstrated for rice, cotton, soybean, sorghum, tomato, corn, grape and apple (Jiang and Vergara 1986; Yadava 1986; Marquard and Tipton 1987; Tenga et al. 1989; Campbell et al. 1990; Dwyer et al. 1991; Fanizza et al. 1991). Reports on maize and rice showed that the linear relationship between SPAD and foliar N content can be improved if foliar $\mathrm{N}$ is expressed as $\mathrm{N}$ mass per leaf area (Chapman and Barreto 1997).

Although SLW together with leaf weight and area in multiple regression increased prediction of $N_{\mathrm{dw}}$ by chlorophyll meter (SPAD) readings (about 96\%), and adjusted SPAD readings for SLW had strong linear correlation with $N_{\text {dw }}\left(r^{2}=0.834\right)$, determination of SLW is a destructive, long, and laborious process. Because a relationship between leaf $\mathrm{N}$ concentration based on leaf area $\left(N_{\mathrm{a}}\right)$ and chlorophyll meter reading provides a simple, rapid, and nondestructive procedure, it is suggested for estimation of leaf $\mathrm{N}$ concentration of semidwarf rice cultivars by SPAD readings.

\section{Conclusion}

Results presented in this study provided strong evidence that there was a statistically significant $(P<0.01)$ relationship between leaf $\mathrm{N}$ concentration and chlorophyll meter (SPAD-502) readings. These relationships may be improved by incorporating specific leaf weight (SLW) into the multiple regression equation, adjusting the SPAD readings for specific leaf weight (SPAD/SLW), or by predicting leaf $\mathrm{N}$ concentration per unit leaf area, instead of $\mathrm{N}$ 
Table 7 Comparison of simple (Italic) and multiple regression models between nitrogen concentration based on leaf dry weight $\left(N_{\mathrm{dw}}\right)$ and chlorophyll meter (SPAD) readings, and LSD values for comparison of simple regression slopes (SRS), specific leaf weight
(SLW), $N_{\mathrm{dw}}$, leaf nitrogen concentration based on leaf area $\left(N_{\mathrm{a}}\right)$ and chlorophyll meter (SPAD) readings at various days after transplanting (DAY)

\begin{tabular}{|c|c|c|c|c|c|c|c|}
\hline \multirow[t]{2}{*}{ DAY } & \multirow[t]{2}{*}{ Regression model } & \multirow[t]{2}{*}{$R_{\mathrm{abj}}^{2}$} & \multirow[t]{2}{*}{ SRS } & \multicolumn{4}{|l|}{ Mean } \\
\hline & & & & SLW $\left(\mathrm{g} \mathrm{m}^{-2}\right)$ & $N_{\mathrm{dw}}\left(\mathrm{g} \mathrm{kg}^{-1}\right)$ & $N_{\mathrm{a}}\left(\mathrm{g} \mathrm{m}^{-2}\right)$ & SPAD readings \\
\hline \multirow[t]{2}{*}{19} & $Y=-54.723+2.986(S P A D)$ & 0.816 & 2.986 & 29.19 & 44.94 & 1.308 & 38.49 \\
\hline & $\mathrm{Y}=2.598(\mathrm{SPAD})-1.17(\mathrm{SLW})$ & 0.912 & & & & & \\
\hline \multirow[t]{2}{*}{29} & $Y=1.311(S P A D)$ & 0.726 & 1.311 & 43.31 & 44.72 & 1.928 & 36.27 \\
\hline & $\mathrm{Y}=27.281+1.444(\mathrm{SPAD})-0.884(\mathrm{SLW})$ & 0.974 & & & & & \\
\hline \multirow[t]{2}{*}{39} & $Y=-71.034+2.867(S P A D)$ & 0.722 & 2.867 & 49.63 & 32.97 & 1.621 & 35.97 \\
\hline & $\mathrm{Y}=-28.734+2.503(\mathrm{SPAD})-0.586(\mathrm{SLW})$ & 0.960 & & & & & \\
\hline \multirow[t]{2}{*}{49} & $Y=-83.412+3.143(S P A D)$ & 0.724 & 3.143 & 50.07 & 26.61 & 1.323 & 35.72 \\
\hline & $\mathrm{Y}=2.354(\mathrm{SPAD})-0.769(\mathrm{SLW})$ & 0.925 & & & & & \\
\hline \multirow[t]{2}{*}{59} & $Y=-26.248+1.367(S P A D)$ & 0.518 & 1.367 & 55.37 & 23.60 & 1.103 & 35.04 \\
\hline & $\mathrm{Y}=11.219-0.371(\mathrm{SLW})+0.0 .843(S P A D)$ & 0.977 & & & & & \\
\hline \multirow[t]{2}{*}{69} & $Y=-29.243+1.407(S P A D)$ & 0.874 & 1.407 & 63.88 & 21.00 & 1.342 & 34.94 \\
\hline & $Y=-15.872+1.509(\mathrm{SPAD})-0.267(\mathrm{SLW})$ & 0.935 & & & & & \\
\hline \multirow[t]{2}{*}{79} & $Y=-60.771+2.346(S P A D)$ & 0.810 & 2.364 & 61.11 & 20.11 & 1.432 & 34.38 \\
\hline & $\mathrm{Y}=-41.894+2.533(\mathrm{SPAD})-0.419(\mathrm{SLW})$ & 0.955 & & & & & \\
\hline \multirow[t]{2}{*}{89} & $Y=-55.184+2.172(S P A D)$ & 0.847 & 2.172 & 69.11 & 19.50 & 1.343 & 33.56 \\
\hline & $\mathrm{Y}=-33.878+2.409(\mathrm{SPAD})-0.426(\mathrm{SLW})$ & 0.988 & & & & & \\
\hline \multirow[t]{3}{*}{99} & $Y=-25.535+1.255(S P A D)$ & 0.761 & 1.255 & 72.60 & 16.57 & 1.197 & 33.36 \\
\hline & $\mathrm{Y}=1.174(\mathrm{SPAD})-0.267(\mathrm{SLW})$ & 0.936 & & & & & \\
\hline & LSD & & 1.376 & 3.509 & 2.021 & 0.072 & 0.889 \\
\hline
\end{tabular}

SPAD Soil and plant analysis development (Minolta Co. Ltd.)

concentration per unit leaf dry weight. These findings showed that SPAD values could be substantially affected by a number of factors, particularly leaf thickness, in addition to chlorophyll concentrations. The best linear regression equation explained $80 \%$ of the variation between SPAD readings and leaf $\mathrm{N}$ concentration per unit leaf area. Part of the unexplained variation may be due to the heterogeneity of leaf thickness and $\mathrm{N}$ distribution in the leaf. Thus, Chlorophyll meter (SPAD-502) as an effective and useful device may assist to identify $\mathrm{N}$ levels for more precise $\mathrm{N}$ management. It can be concluded that the portable N-Tester chlorophyll meter can be used as an easy and fast tool to predict nitrogen status based on leaf area and the critical leaf color grade for use in determining the timing of $\mathrm{N}$ topdressing in the rice plant under field conditions.

Acknowledgments The authors are grateful for technical aids of the soil and water division of Rice Research Institute of Iran (RRII) for measuring leaf $\mathrm{N}$ concentration.

Open Access This article is distributed under the terms of the Creative Commons Attribution Noncommercial License which permits any noncommercial use, distribution, and reproduction in any medium, provided the original author(s) and source are credited.

\section{References}

Balasubramanian V, Morales AC, Cruz RT, Thiyagarajan TM, Nagarajan R, Babu M, Abdulrachman S, Hai LH (2000) Adaptation of the chlorophyll meter (SPAD) technology for real-time $\mathrm{N}$ management in rice: a review. Int Rice Res Notes 25:4-8

Blackmer TM, Schepers JS (1994) Techniques for monitoring crop nitrogen status in corn. Commun Soil Sci Plant Anal 25:17911800

Campbell RJ, Mobley KM, Marini RP, Pfeiffer DG (1990) Growing conditions alter the relationship between SPAD-510 values and apple leaf chlorophyll. HortScience 25:330-331

Chapman SC, Barreto HJ (1997) Using a chlorophyll meter to estimate specific leaf nitrogen of tropical maize during vegetative growth. Agron J 89:557-562

Chapman HP, Pratt PF (1961) Methods of analysis for soil, plant and water. University of California. Division of Agricultural Sciences, Riverside, CA, USA

Chiariello NR, Mooney HA, Williams K (1989) Growth, carbon allocation and cost of plant tissues. In: Pearcy RW, Ehlenger J, Mooney HA, Rundel PW (Eds) Plant physiological ecology. Field methods and instrumentation. Chapman \& Hall, New York, pp. 327-366

Chubachi T, Asano I, Oikawa T (1986) The diagnosis of nitrogen nutrition of rice plant (Sasanishki) using chlorophyll meter. Japan J Soil Sci Plant Nutr 57:190-193

Dwyer LM, Tollenaar M, Houwing L (1991) A nondestructive method to monitor leaf greenness in corn. Can J Plant Sci 71:505-509 
Evans JR (1983) Nitrogen and photosynthesis in the flag leaf of wheat. Plant Physiol 72:297-302

Fanizza G, Della Gatta C, Bagnulo C (1991) A nondestructive determination of leaf chlorophyll in Vitis vinifera. Ann Appl Biol 119:203-205

Jiang XX, Vergara BS (1986) Chlorophyll meter (SPAD-501) to quantify relative cold tolerance in rice. Int Rice Res News Lett 11:10-11

Marquard RD, Tipton JL (1987) Relationship between extractable chlorophyll and an in situ method to estimate leaf greenness. HortScience 22:1327

Minolta (1989) Manual for chlorophyll meter SPAD-502. Minolta Camera Co., Ltd., Japan

Peng S, Garcia FC, Laza RC, Cassman KG (1992) Leaf thickness affects the estimation of leaf nitrogen concentration using a chlorophyll meter. Int Rice Res Notes 17:19-20

Peng S, Garcia FC, Laza RC, Cassman KG (1993) Adjustment for specific leaf weight improves chlorophyll meter's estimation of rice leaf nitrogen concentration. Agron J 85:987-990

Peng S, Cassman KG, Kropff MJ (1995a) Relationship between leaf photosynthesis and nitrogen content of field-grown rice in the tropics. Crop Sci 35:1627-1630

Peng S, Laza RC, Garcia FC, Cassman KG (1995b) Chlorophyll meter estimates leaf area-based $\mathrm{N}$ concentration of rice. Commun Soil Sci Plant Anal 26:927-935
SAS Institute (1996) SAS system for windows. Release 6.12. SAS Inst., Cary, NC

Smeal D, Zhang H (1994) Chlorophyll meter evaluation for nitrogen management in corn. Commun Soil Plant Anal 25:1495-1503

SPSS (1999) SYSTAT User's Guide: Statistics. Version 9.0. SPSS, Inc., Chicago, IL

Taiz L, Zeiger E (1991) Plant physiology. Benjamin/Cummings Pub. Sinauer Associates, Inc

Takebe M, Yoneyama T (1989) Measurement of leaf color scores and its implication to nitrogen nutrition of rice plants. JARQ 23:8693

Tenga AZ, Marie BA, Ormrod DP (1989) Leaf greenness meter to assess ozone injury to tomato leaves. HortScience 24:514

Turner FT, Jund MF (1991) Chlorophyll meter to predict nitrogen topdress requirement for semidwarf rice. Aust J Exp Agric 34:1001-1005

Watanabe S, Hatanaka Y, Inada K (1980) Development of a digital chlorophyll meter. I: Structure and performance. Japan J Crop Sci 49:89-90

Yadava UL (1986) A rapid and nondestructive method to determine chlorophyll in intact leaves. HortScience 22:1449-1450 